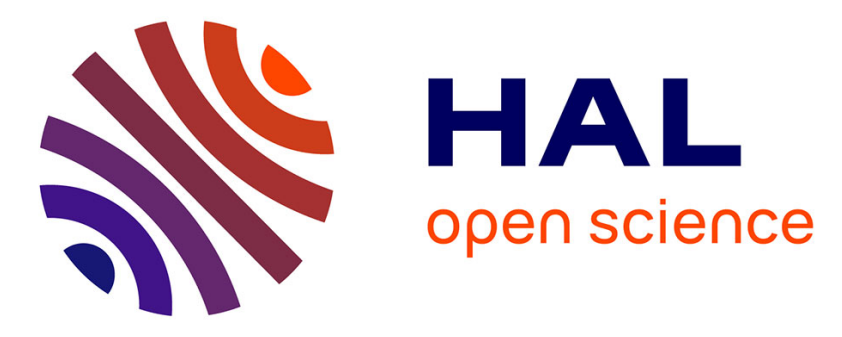

\title{
The mitochondrial citrate carrier: a new player in inflammation
}

Vittoria Infantino, Paolo Convertini, Liana Cucci, Maria Antonietta Panaro, Maria Antonietta Di Noia, Rosa Calvello, Ferdinando Palmieri, Vito Lacobazzi

\section{- To cite this version:}

Vittoria Infantino, Paolo Convertini, Liana Cucci, Maria Antonietta Panaro, Maria Antonietta Di Noia, et al.. The mitochondrial citrate carrier: a new player in inflammation. Biochemical Journal, 2011, 438 (3), pp.433-436. 10.1042/BJ20111275 . hal-00617325

\section{HAL Id: hal-00617325 \\ https://hal.science/hal-00617325}

Submitted on 27 Aug 2011

HAL is a multi-disciplinary open access archive for the deposit and dissemination of scientific research documents, whether they are published or not. The documents may come from teaching and research institutions in France or abroad, or from public or private research centers.
L'archive ouverte pluridisciplinaire HAL, est destinée au dépôt et à la diffusion de documents scientifiques de niveau recherche, publiés ou non, émanant des établissements d'enseignement et de recherche français ou étrangers, des laboratoires publics ou privés. 


\section{THE MITOCHONDRIAL CITRATE CARRIER: A NEW PLAYER IN INFLAMMATION}

V. Infantino ${ }^{*}$, , P. Convertini ${ }^{*}$, L. Cucci ${ }^{\ddagger}$, M. A. Panaro ${ }^{\ddagger}$, M. A. Di Noia ${ }^{*}$, , R. Calvello*, F. Palmieri ${ }^{*}$, , V. lacobazzi ${ }^{*}, \$$

"Department of Pharmaco-Biology, laboratory of Biochemistry and Molecular Biology, University of Bari, 70125 Bari, Italy

${ }^{\dagger}$ Department of Chemistry, University of Basilicata, 85100 Potenza, Italy

${ }^{\ddagger}$ Department of Human Anatomy and Histology, University of Bari, 70124 Bari, Italy

${ }^{\S} \mathrm{CNR}$ Institute of Biomembranes and Bioenergetics, 70125 Bari, Italy

Corresponding author: Vito lacobazzi. Phone +39 080 544-2322, Fax +39 080 544-2770; e-mail: viacob@farmbiol.uniba.it. 


\section{Synopsis}

The citrate carrier $(\mathrm{CIC})$ catalyzes the efflux of citrate from the mitochondrial matrix in exchange for cytosolic malate. Herein we show that $\mathrm{CIC}$ mRNA and protein markedly increase in LPS-activated immune cells. Moreover, CIC gene silencing and CIC activity inhibition significantly reduce production of nitric oxide, reactive oxygen species and prostaglandins. These results demonstrate for the first time that CIC has a critical role in inflammation.

\section{Keywords}

Citrate carrier, immune cells, gene regulation, nitric oxide, reactive oxygen species, prostaglandin E2

\section{Abbreviations}

BTA, 1,2,3-Benzenetricarboxylate; CIC, Citrate carrier; COX2, cyclooxygenase 2; DCFH $2^{-}$ DA, 2',7'-dichlorofluorescein diacetate; ELISA, Enzyme-Linked ImmunoSorbent Assay; IkB, inhibitor of kB; iNOS, the inducible nitric oxide synthase; LPS, lipopolysaccharide; LUC, luciferase; NADPH OX, NADPH oxidase; NF-kB, Nuclear Factor-kappa B; NO, nitric oxide; PMA, Phorbol-12-myristate-13-acetate; PGE2, prostaglandin E2; ROS, reactive oxygen species; siRNA, small interfering RNA; TPCK, N-p-Tosyl-L-phenylalaninechloromethyl-ketone. 


\section{INTRODUCTION}

Inflammation is an immune response to infection, tissue injury and other noxious insults [1]. It is characterized by the production of inflammatory mediators such as cytokines, prostaglandin E2 (PGE2), nitric oxide (NO) and reactive oxygen species (ROS) by cells of the innate and adaptive immune system. The nuclear transcription factor, Nuclear Factor-kappa B (NF-kB), is a pivotal orchestrator of inflammation [2, 3]. Exposure of cells to lipopolysaccharide (LPS) or other pro-inflammatory stimuli leads to the activation of NF-KB which stimulates target gene expression [4]. Many studies have shown that fatty acids modulate NF-kB activation and macrophage functions [5, 6]. However, until now there is no report on the role of the mitochondrial citrate carrier $(\mathrm{CIC})$ in inflammation. CIC is an integral inner mitochondrial membrane protein that catalyses the export of citrate from the mitochondrial matrix in exchange for cytosolic malate [7, 8]. This transporter is essential for fatty acid biosynthesis because citrate in the cytosol is cleaved to acetyl-CoA and oxaloacetate by citrate lyase. Acetyl-CoA is directly used for fatty acid synthesis, and oxaloacetate produces NADPH $+\mathrm{H}^{+}$(also necessary for fatty acids production) via malate dehydrogenase and malic enzyme [9].

In this study we show that CIC expression increase in LPS-activated immune cells and $\mathrm{CIC}$ silencing as well as $\mathrm{CIC}$ activity inhibition reduces the production of NO, ROS and PGE2 in LPS-activated U937 cells. Moreover, evidence is provided that CIC gene expression is upregulated by NF-kB. To our knowledge, this is the first study to state the $\mathrm{CIC}$ key role in the production of inflammation mediators.

\section{EXPERIMENTAL}

\section{Cell culture, RNA interference, and transient transfection}

The peripheral blood mononuclear cell (PBMC) fraction was obtained as reported in Supplementary experimental. Human monocytic/macrophage cells from hystiocytoma, U937 cells (ICLC HTL 94002-Interlab Cell Line Collection), were cultured as described for PBMC (see Supplementary experimental). U937 cells were differentiated with $10 \mathrm{ng} / \mathrm{ml}$ of phorbol-12-myristate-13-acetate (PMA, Sigma) and allowed to adhere for $24 \mathrm{~h}$. Where indicated, both macrophages and U937/PMA (differentiated U937) cells were treated with $2 \mu \mathrm{g} / \mathrm{ml}$ of bacterial lipopolysaccharide (LPS, Sigma) for $24 \mathrm{~h}$; U937/PMA cells were treated with $20 \mu \mathrm{M}$ of $\mathrm{N}$-p-Tosyl-L-phenylalanine-chloromethyl-ketone (TPCK, Sigma) for 1 $\mathrm{h}$ and then with LPS $(2 \mathrm{\mu g} / \mathrm{ml})$ for $24 \mathrm{~h}$; and U937/PMA cells were treated with $2 \mathrm{mM}$ of 1,2,3-benzentricarboxylic acid (BTA, Sigma) for $4 \mathrm{~h}$ and then with LPS $(2 \mu \mathrm{g} / \mathrm{ml})$ for $24 \mathrm{~h}$ (NO and ROS measurements) and for $48 \mathrm{~h}$ (PGE2). In the latter case to favor the entry of BTA into the cells, $25 \mu \mathrm{l}$ of a 6:1 (v/v) mixture of Fugene HD (Roche) and RPMI 1640 medium with and without BTA at final $\mathrm{pH} 7.3$, were added to $500 \mu \mathrm{l}$ of U937/PMA cells. After $4 \mathrm{~h}$, the medium was replaced with fresh medium and the BTA-treated U937/PMA cells were incubated with LPS $(2 \mu \mathrm{g} / \mathrm{ml})$.

To measure CIC gene expression activity, U937/PMA cells were transiently transfected as previously reported [10] using $0.5 \mu \mathrm{g}$ of pGL3 basic-LUC vector, containing the $-1785 /-20$ bp region of the CIC gene promoter [11] and $10 \mathrm{ng}$ of pRL-CMV (Promega) to normalize the extent of transfection [12]. After $24 \mathrm{~h}$ transfected U937/PMA cells were treated with LPS $(2 \mu \mathrm{g} / \mathrm{ml})$ and after further $24 \mathrm{~h}$ were assayed for LUC activity using the Dual-Luciferase ${ }^{\circledR}$ Reporter Assay System (Promega). In RNA interference experiments, U937 cells were differentiated by adding PMA and simultaneously transfected with the specific pre-designed small interfering RNA (siRNA) targeting human SLC25A1 (s13095, Ambion) using siPORT ${ }^{\mathrm{TM}}$ NeoFX ${ }^{\mathrm{TM}}$ Transfection Agent (Ambion). After $24 \mathrm{~h}$, the medium 
was replaced with fresh medium and the siRNA-transfected U937/PMA cells were treated with LPS $(2 \mu \mathrm{g} / \mathrm{ml})$; CIC mRNA and protein, ROS and NO were measured $24 \mathrm{~h}$ after the addition of LPS, while PGE2 was measured $48 \mathrm{~h}$ after the addition of LPS. In these experiments, siRNA (Cat. No. C6A-0126, Ambion) with no significant similarity to human, mouse, or rat gene sequences was used as negative control.

\section{Real-time PCR and western blotting}

Total RNA was extracted from $1 \times 10^{6}$ U937 cells and reverse transcripted as reported [13]. Real-time PCR was performed as previously described [14]. Assay-ondemand for human CIC (Hs00761590_sH) and human $\beta$-actin (4326315E) were purchased from Applied Biosystems. All transcript levels were normalized against the $\beta-$ actin expression levels. For Western blot analysis, proteins were electroblotted onto nitrocellulose membranes (Bio-Rad) and treated with anti-CIC [15] or anti- $\beta$-actin (Santa Cruz Biotechnology) antibodies. The immunoreaction was detected by immobilon Western Chemiluminescent HRP Substrate (Millipore).

\section{NO, ROS and PGE2 detection}

Nitrite, the oxidation product of NO, was measured by the Griess reaction [16]. For ROS analysis the cells were incubated with $10 \mu \mathrm{M} \mathrm{DCFH} \mathrm{H}_{2}$-DA (Molecular Probes) for 30 min. The fluorescence was revealed by Victor ${ }^{3}$ plate reader (Perkin-Elmer) at $485 \mathrm{~nm}$ excitation and $530 \mathrm{~nm}$ emission wavelengths [17]. PGE2 was detected by the DetectX High Sensivity PGE2 Enzyme Immunoassay Kit (K018-HX1) according to the manufacturer's instructions (Arbor Assays).

\section{RESULTS}

\section{Expression of mitochondrial CIC in LPS-activated macrophages and U937 cells}

If activated by an inflammatory stimulus, macrophages synthesize and release modulators of inflammation, such as the eicosanoid PGE2 [18]. Because eicosanoids originate from fatty acids, in particular from arachidonic acid, we investigated whether the upstream process of the fatty acid synthesis pathway, i.e. the exit of citrate from the mitochondrial matrix and the production of acetyl-CoA, is involved in the inflammatory signaling. Acetyl-CoA is produced by citrate lyase, which cleaves the citrate transported from the mitochodria to the cytosol by CIC. Total RNA, extracted from primary blood monocytes, macrophages and LPS-stimulated macrophages, was retrotranscripted and used in real-time PCR experiments. Surprensingly, an increase of about 15-fold and 28fold of CIC mRNA was found in monocyte-derived macrophages and LPS-stimulated macrophages, respectively, compared to undifferentiated monocytes (Figure 1A). Consistently, a parallel increase of CIC protein content in macrophages after differentiation and after activation by LPS was found (Figure 1B).

In subsequent experiments we used differentiated U937 cells which have a large repertoire of macrophage functions and can be stimulated with LPS to mimic the inflammatory response of activated macrophages [19]. Both real-time PCRs and Western blots revealed that CIC mRNA and protein levels were increased in U937/PMA cells and even more in LPS-activated U937 cells as compared to untreated U937 cells, although to a lesser extent than macrophages in the presence and absence of LPS as compared to monocytes (Figures 1C and 1D). 
These findings clearly show that $\mathrm{CIC}$ expression significantly increases in immune system cells suggesting that $\mathrm{CIC}$ can play a role in inflammation.

\section{Effect of CIC silencing on the production of inflammatory molecules}

To understand the role of $\mathrm{CIC}$ in the inflammatory pathway we extended our investigation on a possible relationship between $\mathrm{CIC}$ expression and molecules involved in inflammation. U937 cells were transfected with siRNA targeting human $\mathrm{ClC}$ or control siRNA, differentiated by adding PMA, stimulated with LPS and assayed for CIC expression, NO, ROS and PGE2 levels. CIC silencing efficiency was confirmed by significantly decrease of CIC mRNA and protein levels (Figure 1S). The amount of NO, ROS and PGE2 was significantly decreased in silenced PMA-differentiated, and LPSstimulated U937 cells as compared to non-silenced cells (Figure 2).

These results indicate a direct involvement of $\mathrm{CIC}$ in the inflammatory pathway.

\section{Effect of the CIC-inhibitor BTA on the LPS-induced inflammation}

We also tested the effect of BTA, a specific inhibitor of CIC [20, 21], on the production of the inflammatory mediators NO, ROS and PGE2. In this case U937/PMA cells were treated with BTA, activated by LPS and assayed for NO, ROS, PGE2. As shown in Figure 3 a marked reduction in NO, ROS and PGE2 production was found in BTA-treated U937 cells compared to untreated cells. The BTA delivery into the cells was also verified by staining intracellular lipids (Figure $2 \mathrm{~S}$ ).

These results show that CIC activity is essential for the production of the inflammatory mediators NO, ROS and PGE2.

\section{The CIC gene promoter contains NF-kB active responsive elements}

Finally, to clarify molecular mechanisms responsible for $\mathrm{CIC}$ gene activation during inflammation we performed in silico analysis of the human $\mathrm{CIC}$ gene promoter and we found two NF-kB responsive elements. NF-kB binding site activity was tested by transfecting LPS-activated U937/PMA cells with the pGL3 basic-LUC vector containing the $-1785 /-20$ bp region of the CIC gene in the presence or absence of TPCK, a specific NF$\mathrm{kB}$ inhibitor [22]. Figure 4A shows that the luciferase gene reporter activity was about $50 \%$ lower in cells transfected with the CIC-pGL3 basic-LUC vector in the presence of TPCK (black bar) than with the vector in the absence of TPCK (white bar). Moreover, when U937/PMA cells were treated with both LPS and TPCK a reduction of CIC mRNA and protein levels was observed as compared to cells treated with LPS alone (Figures 4B and 4C). It is worth mentioning that NO, ROS and PGE2 contents measured in TPCK-treated cells were also diminished as expected (data not shown).

These results show that the increased CIC gene expression in LPS-activated U937 cells is mediated by NF-kB and $\mathrm{CIC}$ gene represents a newly identified target of the inflammatory cascade.

\section{DISCUSSION}

Until now CIC function has been mainly related to liver and pancreas metabolism. For the first time, we show here that $\mathrm{CIC}$ is involved in inflammation. Among the reported results, the following supporting evidence can be mentioned. Both CIC transcript and protein levels greatly increase when macrophages or differentiated U937 cells are 
activated by LPS. Moreover, CIC gene silencing and CIC activity inhibition drastically reduce the production of the inflammatory mediators NO, ROS and PGE2.

The outcome of our experiments can be explained on the basis of the important role played by $\mathrm{CIC}$ in intermediary metabolism. Indeed, CIC supplies acetyl-CoA necessary for PGE2 synthesis and $\mathrm{NADPH}+\mathrm{H}^{+}$for $\mathrm{NO}$ and ROS production (Figure 5). At the same time, CIC gene expression is activated by NF-kB, the hallmark of inflammation which activates virtually all the genes whose expression is crucial in driving the inflammatory response [23]. In fact, TPCK, a specific NF-kB inhibitor, strongly reduces CIC transcription in the inflammatory response.

Thus, it seems reasonable to conclude that PEG2, ROS and NO increase in inflammation by NF-kB direct effect not only on COX2, iNOS and NADPH oxidase genes but also on $\mathrm{CIC}$ gene which causes an increased availability of cytosolic acetyl-CoA and $\mathrm{NADPH}+\mathrm{H}^{+}$needed for synthesis of all above mentioned mediators. Furthermore, macrophages activation involves profound transcriptional and translational modifications leading among others to changes in cellular metabolism [24]. So other mitochondrial carriers, which catalyse the translocation of solutes across the inner mitochondrial membrane, may display altered expression levels and play a role in activated macrophages.

\section{FUNDING}

This work was supported by grants from MIUR, the Center of Excellence in Genomics (CEGBA), the Fondazione Cassa di Risparmio di Puglia, the Apulia region, and the Italian Human ProteomeNet No. RBRN07BMCT_009.

\section{REFERENCES}

1 Medzhitov, R. (2010) Inflammation 2010: new adventures of an old flame. Cell. 140, 771-776

2 Baldwin, A. S. (1996) The NF-kappa B and I kappa B proteins: new discoveries and insights. Annu. Rev. Immunol. 14, 649-683

3 Ghosh, S. and Hayden, M. S. (2008) New regulators of NF-kappaB in inflammation. Nat. Rev. Immunol. 8, 837-848

4 Ghosh, S. and Karin, M. (2002) Missing pieces in the NF-kappaB puzzle. Cell. 109 Suppl, S81-96

5 Yaqoob, P. (1998) Lipids and the immune response. Curr. Opin. Clin. Nutr. Metab. Care. 1, 153-161

6 Calder, P. C. and Grimble, R. F. (2002) Polyunsaturated fatty acids, inflammation and immunity. Eur. J. Clin. Nutr. 56 Suppl 3, S14-19

7 Kaplan, R. S., Mayor, J. A. and Wood, D. O. (1993) The mitochondrial tricarboxylate transport protein. cDNA cloning, primary structure, and comparison with other mitochondrial transport proteins. J. Biol. Chem. 268, 13682-13690

8 Bisaccia, F., De Palma, A., Dierks, T., Kramer, R. and Palmieri, F. (1993) Reaction mechanism of the reconstituted tricarboxylate carrier from rat liver mitochondria. Biochim. Biophys. Acta. 1142, 139-145

9 Palmieri, F. (2004) The mitochondrial transporter family (SLC25): physiological and pathological implications. Pflugers Arch. 447, 689-709

10 Convertini, P., Infantino, V., Bisaccia, F., Palmieri, F. and lacobazzi, V. (2011) Role of FOXA and Sp1 in mitochondrial acylcarnitine carrier gene expression in different cell lines. Biochem. Biophys. Res. Commun. 404, 376-381 
11 Infantino, V., lacobazzi, V., De Santis, F., Mastrapasqua, M. and Palmieri, F. (2007) Transcription of the mitochondrial citrate carrier gene: role of SREBP-1, upregulation by insulin and downregulation by PUFA. Biochem. Biophys. Res. Commun. 356, 249-254

12 lacobazzi, V., Convertini, P., Infantino, V., Scarcia, P., Todisco, S. and Palmieri, F. (2009) Statins, fibrates and retinoic acid upregulate mitochondrial acylcarnitine carrier gene expression. Biochem. Biophys. Res. Commun. 388, 643-647

13 lacobazzi, V., Infantino, V., Costanzo, P., Izzo, P. and Palmieri, F. (2005) Functional analysis of the promoter of the mitochondrial phosphate carrier human gene: identification of activator and repressor elements and their transcription factors. Biochem. J. 391, 613621

14 Iacobazzi, V., Infantino, V. and Palmieri, F. (2008) Epigenetic mechanisms and Sp1 regulate mitochondrial citrate carrier gene expression. Biochem. Biophys. Res. Commun. $376,15-20$

15 lacobazzi, V., Infantino, V., Convertini, P., Vozza, A., Agrimi, G. and Palmieri, F. (2009) Transcription of the mitochondrial citrate carrier gene: identification of a silencer and its binding protein ZNF224. Biochem. Biophys. Res. Commun 386, 186-191

16 Green, L. C., Wagner, D. A., Glogowski, J., Skipper, P. L., Wishnok, J. S. and Tannenbaum, S. R. (1982) Analysis of nitrate, nitrite, and [15N]nitrate in biological fluids. Anal. Biochem. 126, 131-138

17 Wang, H. and Joseph, J. A. (1999) Quantifying cellular oxidative stress by dichlorofluorescein assay using microplate reader. Free Radic. Biol. Med. 27, 612-616

18 Sirois, P., Cadieux, A., Rola-Pleszcynski, M. and Bégin, R. (1982) Perifused alveolar macrophages. A technique to study the effects of toxicants on prostaglandin release. Experientia. 38, 1125-1127

19 Baek, Y. S., Haas, S., Hackstein, H., Bein, G., Hernandez-Santana, M., Lehrach, H., Sauer, S. and Seitz, H. (2009) Identification of novel transcriptional regulators involved in macrophage differentiation and activation in U937 cells. BMC Immunol. 10, 18

20 Palmieri, F., Quagliariello, E. and Klingenberger, M. (1972) Kinetics and specificity of the oxoglutarate carrier in rat-liver mitochondria. Eur. J. Biochem. 29, 408-416

21 Bisaccia, F., De Palma, A. and Palmieri, F. (1989) Identification and purification of the tricarboxylate carrier from rat liver mitochondria. Biochim. Biophys. Acta. 977, 171-176

22 Abate, A. and Schröder, H. (1998) Protease inhibitors protect macrophages from lipopolysaccharide-induced cytotoxicity: possible role for NF-kappaB. Life Sci. 62, 10811088

23 Sharif, O., Bolshakov, V. N., Raines, S., Newham, P. and Perkins, N. D. (2007) Transcriptional profiling of the LPS induced NF-kappaB response in macrophages. BMC Immunol. 8, 1

24 Emre, Y. and Nübel, T. (2010) Uncoupling protein UCP2: When mitochondrial activity meets immunity. FEBS Lett. 584, 1437-1442

\section{FIGURE LEGENDS}

Figure 1. CIC expression in immune cells. (A and C) Total RNA from monocytes (Mono), macrophages (Macro), LPS-treated macrophages (Macro + LPS), U937 cells, U937/PMA cells, LPS-treated U937/PMA (U937/LPS) cells was used to quantify CIC mRNA. Means \pm SD of three duplicate independent experiments are shown; differences between samples and relative controls were significant ( $P \ll 0.05$, one-way ANOVA). (B and D) $\mathrm{CIC}$ and $\beta$-actin of the immune cells, shown in $A$ and $C$, respectively, were immunodecorated with specific antibodies. 
Figure 2. Effect of CIC silencing on inflammatory response. U937 cells, differentiated and transfected with the siRNA targeting human $\mathrm{CIC}(+)$ or control siRNA (-), were treated with LPS and then used to quantify NO, ROS and PGE2. Means \pm SD of six duplicate independent experiments are shown; differences between samples and relative controls were significant $(P \ll 0.05$, one-way ANOVA).

Figure 3. Effect of CIC activity inhibition on inflammatory response. U937/PMA cells, treated with (+) or without (-) BTA, activated with LPS and assayed for NO, ROS and PGE2. Means \pm SD of six duplicate independent experiments are shown; differences between samples and relative controls were significant ( $P<<0.05$, one-way ANOVA).

Figure 4. Effect of TPCK on CIC gene expression. (A) U937/PMA cells, transfected with the pGL3 basic-LUC vector containing the $-1785 /-20$ bp region of the CIC gene promoter and incubated with (+) or without (-) TPCK, were treated with LPS and assayed for LUC activity. (B) U937/PMA cells, incubated with (+) or without (-) TPCK, were treated with LPS and used to quantify CIC mRNA. In A and B means \pm SD of five duplicate independent experiments are shown; differences between samples and relative controls were significant ( $P \ll 0.05$, one-way ANOVA). (C) CIC and $\beta$-actin of U937/PMA cells treated as in $B$ were immunodecorated with specific antibodies.

Figure 5. Role of CIC in inflammation. Following LPS stimulation, activated IKKs induce the phosphorylation of IkBs and the release of NF-kB. In the nuclei, NF-kB bind to NF-kB responsive elements and activate target genes, such as $\mathrm{CIC}$, the inducible nitric oxide synthase (iNOS), NADPH oxidase (NADPH OX), cyclooxygenase (COX2) and phospholipase A2 (PLA2). Arrows marked with + indicate activation. Other abbreviations: TLR4, toll-like receptor 4; IKKs, IkB kinase; IkB, inhibitor of kB; CL, ATP-citrate lyase; $\mathrm{OAA}$, oxaloacetate; $\mathrm{MDH}$, malate dehydrogenase. 


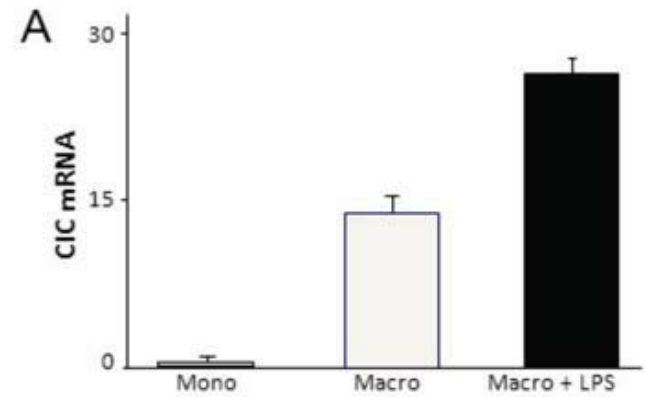

B

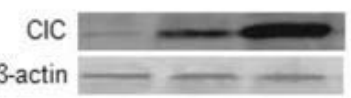

C

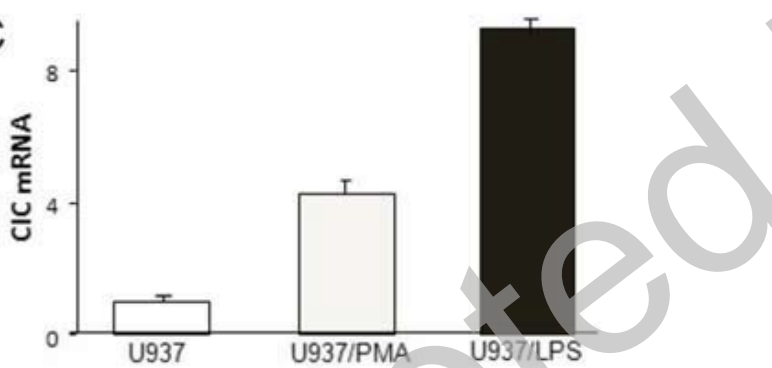

D

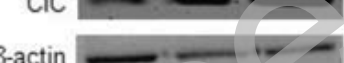

B-actin

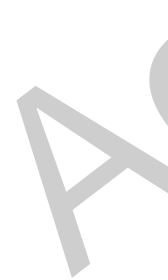

Licenced copy. Copying is not permitted, except with prior permission and as allowed by law. (c) 2011 The Authors Journal compilation (C) 2011 Portland Press Limited 


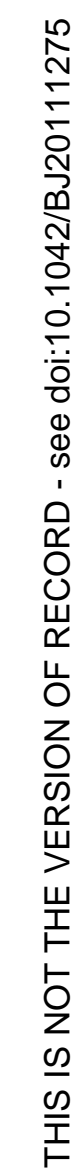
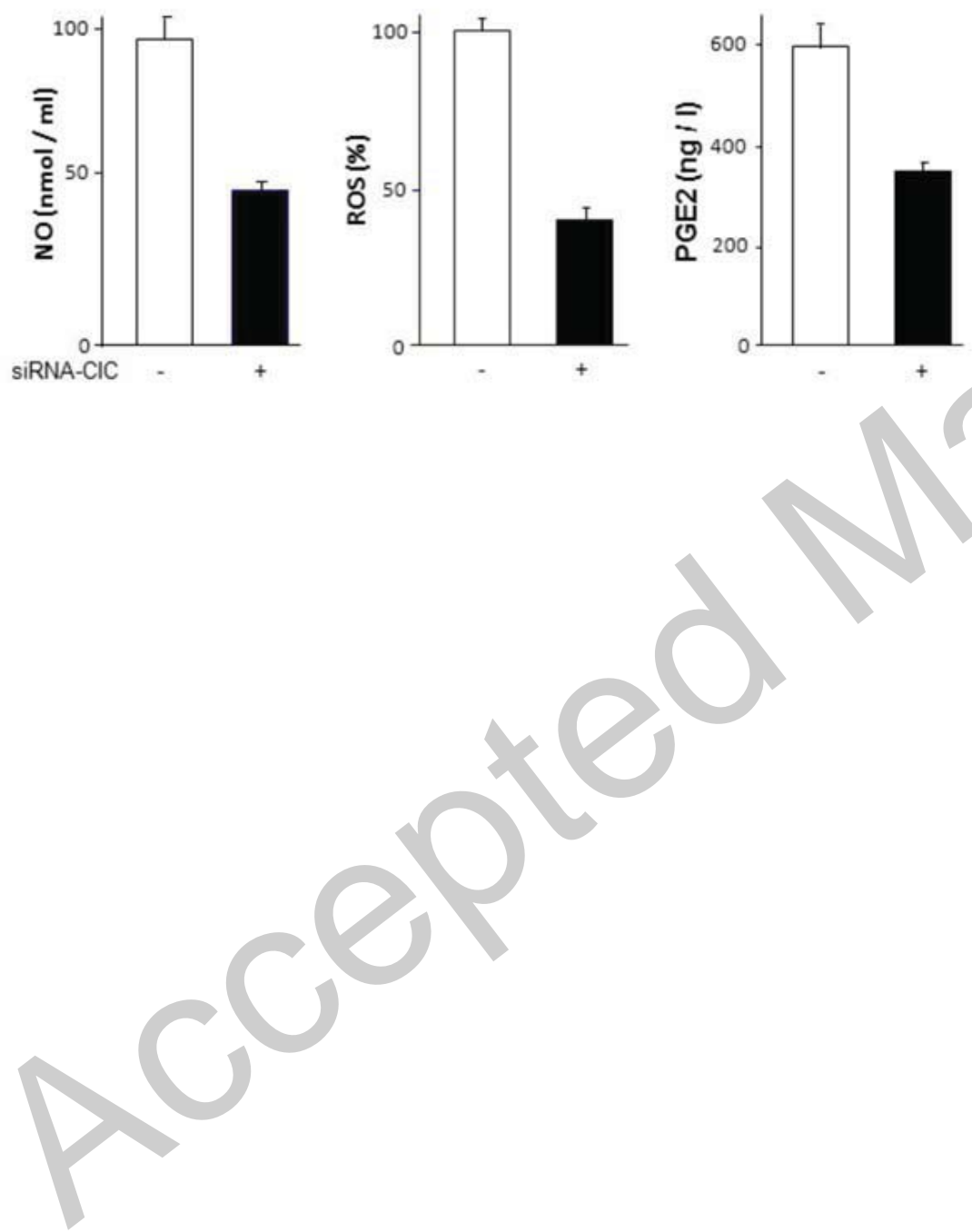

Licenced copy. Copying is not permitted, except with prior permission and as allowed by law. (c) 2011 The Authors Journal compilation (c) 2011 Portland Press Limited 

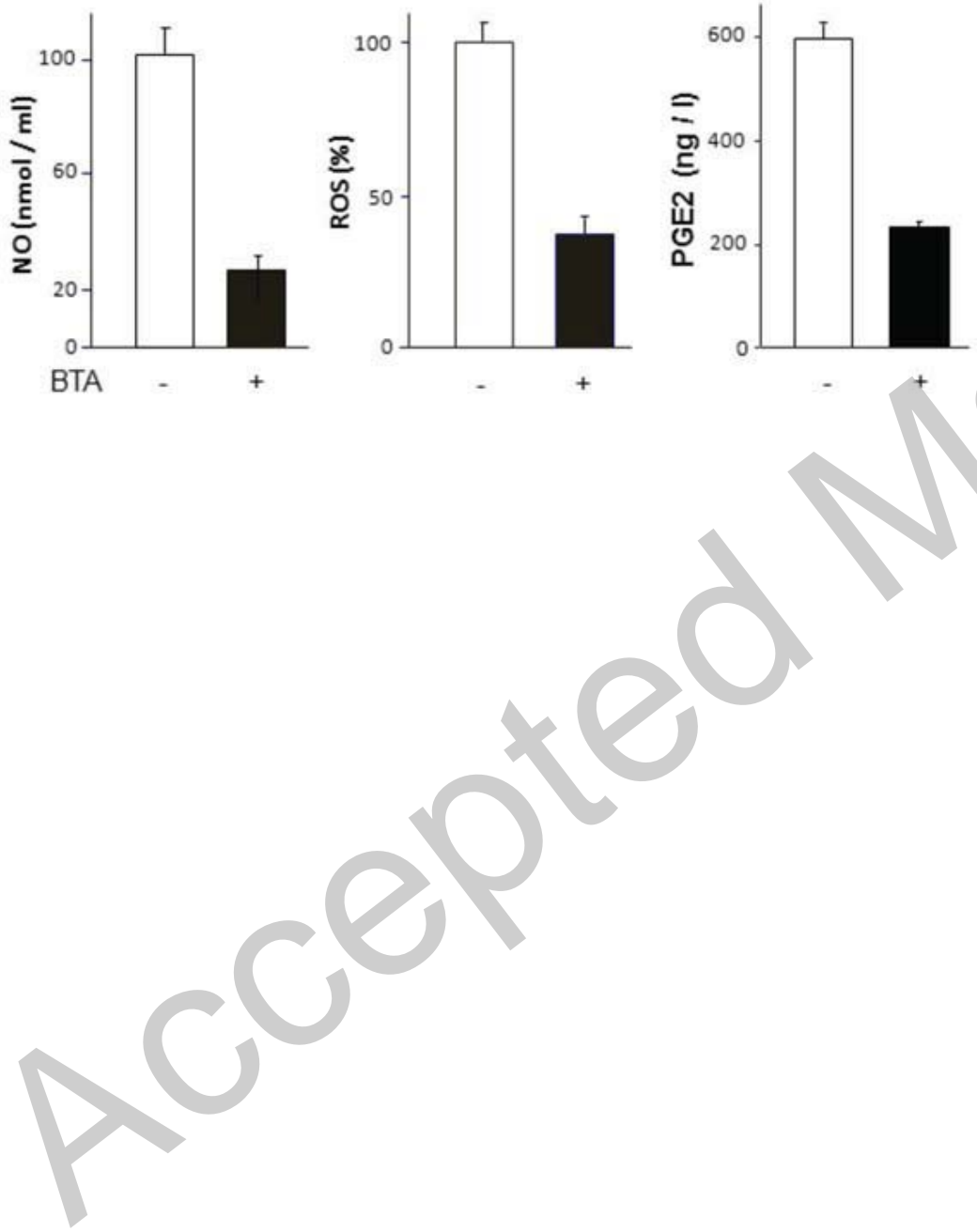

Licenced copy. Copying is not permitted, except with prior permission and as allowed by law. (C) 2011 The Authors Journal compilation (C) 2011 Portland Press Limited 

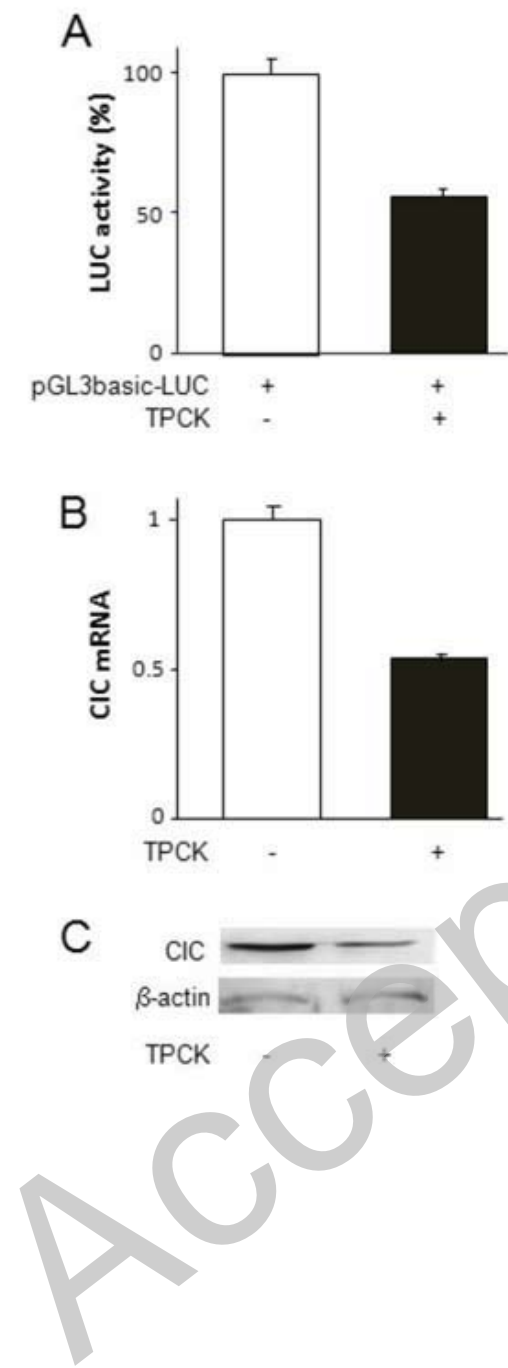

Licenced copy. Copying is not permitted, except with prior permission and as allowed by law. (C) 2011 The Authors Journal compilation (C) 2011 Portland Press Limited 


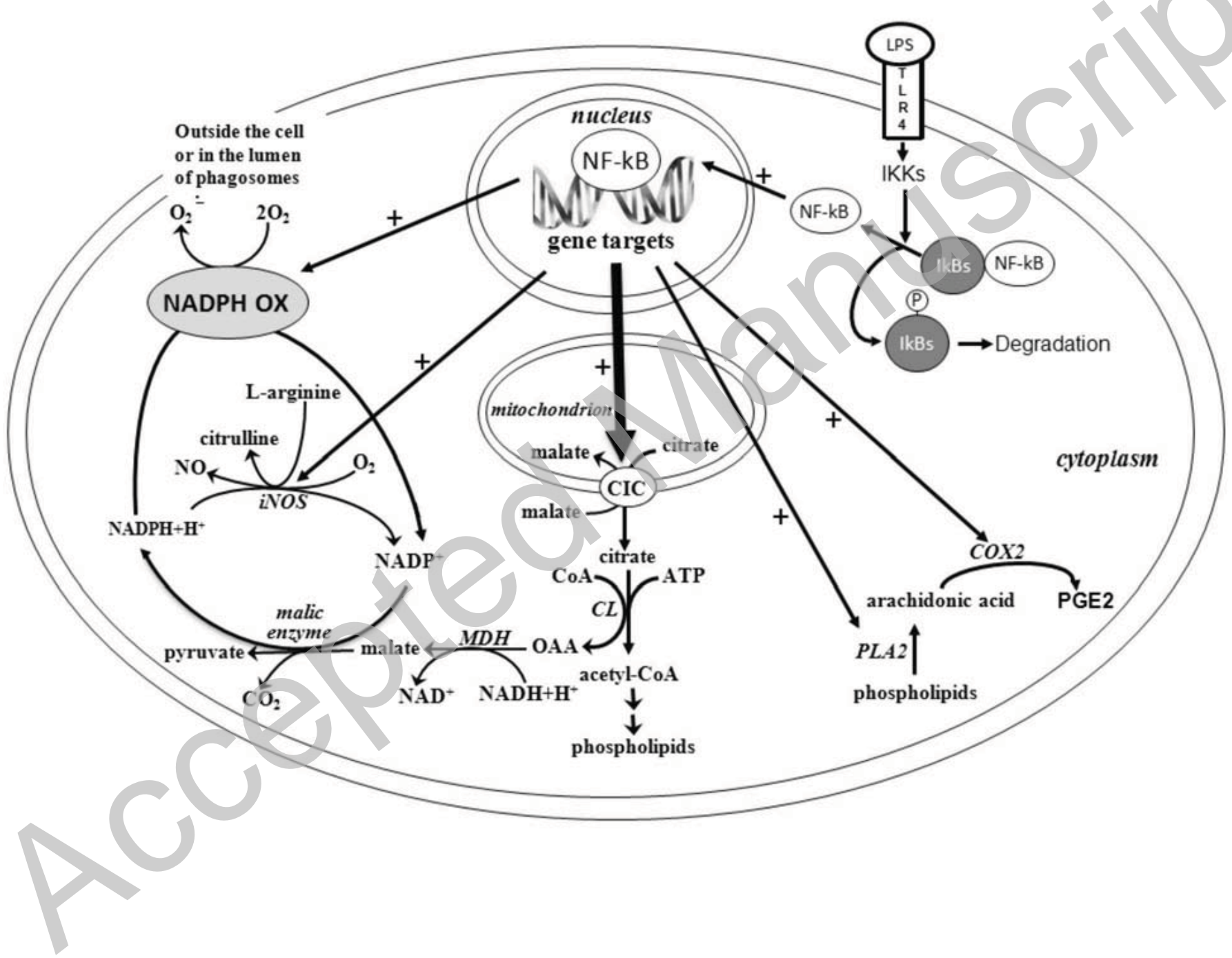

